https://doi.org/10.18485/iipe_euchanges.2021.ch11

\title{
REDEFINING RUSSIA-EUROPEAN UNION RELATIONS - IS IT POSSIBLE TO OVERCOME A DEEP CRISIS?
}

\author{
Ana JOVIĆ-LAZIĆ ${ }^{1}$ \\ Ivona LAĐEVAC ${ }^{2}$
}

\begin{abstract}
The subject of the research is the analysis of the complex relations between Russia and the EU. The article aims to present how these relations have changed from cooperation and the so-called strategic partnership to a new era in which the tension between them has reached a critical point. The current crisis is the result of relations that have been damaged over time by differing expectations on both sides and a lack of mutual understanding leading to increased tensions and geopolitical rivalries that have, inter alia, affected countries physically located between them. The conflict in Georgia made it clear that interactions between the EU and Russia have been highly complicated, but the Ukrainian crisis has become a turning point in their relations, suggesting irreconcilable differences in their regional policy and approaches to the common neighbourhood. Irrespective of such a difficult issue, it is indicated that the continuation of mutual sanctions and confrontational statements will only further weaken the prospects for resolving the current complex situation. It is concluded that cooperation between Russia and the EU is inevitable, especially when it comes to their common neighbourhood and the need to respond more
\end{abstract}

\footnotetext{
${ }^{1}$ Research Fellow, Institute of International Politics and Economics, Belgrade, Serbia. E-mail: anajovic@diplomacy.bg.ac.rs;

The paper presents findings of a study developed as a part of the research project "Serbia and challenges in international relations in 2021 ", financed by the Ministry of Education, Science, and Technological Development of the Republic of Serbia, and conducted by Institute of International Politics and Economics, Belgrade

${ }^{2}$ Research Fellow, Institute of International Politics and Economics, Belgrade, Serbia. E-mail: ivona@diplomacy.bg.ac.rs
} 
effectively to open security threats and issues of importance for contemporary international relations.

Keywords: Russian Federation, European Union, cooperation, crisis, sanctions, common neighbourhood.

\section{INTRODUCTORY REMARKS}

The Russian Federation and the European Union besides being neighbours are among the most influential international actors. These are the main reason why their relations are of great political, economic, and security significance. Unlike Russia, which is a classic sovereign state, the $\mathrm{EU}$ is a unique supranational organization with competences in the areas entrusted to it by the member states. Nevertheless, both sides do have strong and long-term interests to cooperate. Relations between them have changed over time - from the USSR's bilateral cooperation with some European countries, through pragmatic but stagnant relations and cooperation within the Partnership and Cooperation Agreement and the officially declared Strategic Partnership, through a decade in which it was clear that relations were becoming increasingly tense and mutual trust was declining. The lack of mutual understanding and differences in expectations from this relation especially affected Russia's foreign policy strategies and contacts with the West. Although relations between the EU and Russia have gradually deteriorated since the 'coloured revolutions' in the post-Soviet countries in the early 2000s, the armed conflict in Georgia in 2008 and the outbreak of the Ukrainian crisis in 2014, they have entered a new and very difficult confrontational phase. As a consequence, certain initiatives and forms of cooperation established over the years have been suspended and mutual sanctions imposed. The opportunity to build a real strategic partnership between Russia and the EU has been missed. Such disrupted relationships have large political, economic, military and security implications on the regional and global levels.

We often find very simplified explanations about the reasons why the relations between Russia and the EU, as well as the West in general, have deteriorated. Some of them blame either the West or Russia in general or, in particular, Vladimir Putin's policy decisions. The most common argument supporting Russian interests is that the relationship has been constantly degraded because the West has not paid much attention to Russian calls for its interests to be taken into account. In this context, the West should not have extended NATO to the East, built an anti-ballistic missile shield, 
supported democracy and 'colourful revolutions' in the post-Soviet space, or established an EU Eastern Partnership with the post-Soviet states. Russia's stance towards the West might be considered defensive.

The crisis in EU-Russia relations is mainly the result of a long period of stagnation, instability, and mutual misunderstanding. This kind of misunderstanding is the result of the circumstances in which both sides often misinterpret certain political actions, priorities, and strategies of the foreign policy of the other side. This paper does not support either side but seeks to analyse the complexity of the deeply worrying EU-Russia relations in order to contribute to the debate on their possible redefinition. By doing so, we should be aware of the significance and implications of relations between the Union and Russia, bearing in mind the European Union's economic and political importance, and the reality that Russia is a Eurasian power with global interests and ambitions.

If we want to analyse important aspects of contemporary relations between Russia and the EU, we need to understand the evolution and chronological overview of the key stages in their relations. In that sense, the authors will present a historical overview of the mutual relations and the institutional and political structures that have developed over time to outline key assumptions underpinning current mutual relations. References are made to past events that the authors consider to have an impact on the shaping of current relations between the European Union and Russia. After that, the authors will discuss the limitations that have always existed in EU-Russia relations. Various explanations will be presented as well, which will explain why the relations between the EU and Russia did not develop their full potential even before the Ukrainian crisis. Finally, the possibilities for overcoming the deep crisis in the relations between the EU and Russia are pointed out, which might be beneficial for both sides, as well as the broader international community.

\section{ESTABLISHING RELATIONS BETWEEN THE EUROPEAN COMMUNITY AND THE USSR AND DEVELOPMENT OF COOPERATION BETWEEN EU-RUSSIA DURING THE 1990s}

Cooperation between the European Community (EC) and the Union of the Soviet Socialist Republics (USSR) was restricted by the "Cold War" logic and approach. The EC did not particularly deal with relations with the USSR except as a leading power and the founder of the opposing bloc. The Soviet Union as well did not have an interest in developing cooperation with the EC. Moscow saw the European Community as another creation in the 
interest of US policy, aimed at limiting the overall Soviet influence. (Adomeit, 1979, p. 20). The USSR was focused on economic cooperation with the socialist countries of Central and Eastern European Countries through the Council for Mutual Economic Assistance (Comecon). The EC's economic growth was a problem for the government of the USSR, which, despite alleged modernization, failed to lead to similar economic growth. Since the 1970s, the USSR economy has been in a poor-state. The national economy has been slowly declining, and financing of the army race became ever more complicated (Jović-Lazić, 2015, pp. 31-32).

Since Gorbachev took power in the mid-1980s, there have been shifts in the USSR's foreign policy. In Checkel's view, these changes in foreign policy were the result of a complex interaction of both external factors and various domestic influences (Checkel, 1993, p. 297). The USSR during Gorbachev began to see the European Community as an autonomous international force. It began to see the European Community as an autonomous international force. Economic and political reforms became the priorities of the new USSR government, which were to lead to the strengthening of the Soviet economy and its gradual integration into the world economy. It was intended to avoid the USSR's complete economic collapse, and the European Community was a natural partner in those efforts. Cooperation with the EC was seen as a viable foreign policy option that did not pose an economic and military challenge to the USSR and opened up new development opportunities. (Trofimenko, 1991, pp. 3-27).

In 1988, a Joint Declaration was signed between the European Community and the Comecon, which marked mutual legal recognition. ${ }^{3}$ This enabled the establishment of economic ties between the USSR and Western European countries and marked a significant step towards normalizing mutual relations. Mutual recognition created the preconditions for the EC and the USSR to sign an Agreement on trade and commercial and economic cooperation in December 1989, which abolished the EC's quantitative restrictions on imports of goods (excluding coal, steel, and textiles) from the USSR. ${ }^{4}$ A qualitatively new framework was established,

\footnotetext{
${ }^{3}$ Signing of the EC/COMECON Joint Declaration, 24 June 1988, retrieved from https:/ / ec.europa.eu/commission/presscorner/detail/en/MEMO_88_97, Accessed 20 July 2020.

${ }^{4}$ Agreement between the European Economic Community and the European Atomic Energy Community and the Union of Soviet Socialist Republics on trade and commercial and economic cooperation, 1989.
} 
removing obstacles from the EC-USSR cooperation, and ideologically based doubts were replaced by pragmatic realism.

After the Cold War's end, and the Soviet Union's fall, the military bloc that it steered dissolved, and that led to major changes in international relations. Russia, the biggest state that arose from the ashes of the Soviet Union, could hardly qualify as the successor of a similar reputation and influence. Early in the 1990s, Russia was in a complicated situation, with serious economic, ethnic, and political problems. The biggest challenge was to develop efficient state institutions capable to defend territorial integrity, stop tendencies of disintegration, and begin economic reforms. Although Russia lost its role as a global superpower, due to its size, geographical position, overall capabilities, and military and other potential, it remained a key factor in the area of stability and security. Russia, as the Soviet Union's successor state, kept the role of a nuclear superpower, Europe's largest conventional military force, and a permanent member of the UN Security Council. Accordingly, Russia participated, directly and indirectly, in the political, economic, military, and the security reconfiguration of Europe that followed, although it did not play a leading role in it (Webber, 2000, p. 66). As Haukkala points out, Russia needed strong economic and political support to find its place in the new post-Cold War era. Russia was convinced that it deserved it, considering that due to its goodwill the Cold War ended with an agreement (Haukkala, 2015, pp. 25-26). Russia was acting as the socalled pro-status quo force because it valued its position as the successor of one of the super-powers in the Cold War. Also, its foreign policy contained elements such as conservatism and discontent with the current state of international relations. The Russian Federation, for its part, sought to keep a special relationship with the countries that emerged from the USSR's territory and position itself as a leader in the accomplishment of their key security, political, economic, and other interests. At the end of 1991, the Community of Independent States was formed, which provided a kind of political and international legal framework for the peaceful disintegration of the USSR.

While the USSR was in the transformation process, the EC Member States, on the other hand, agreed to create the European Union and to significantly improve their economic, political, security, and foreign policy cooperation. The EU since that time has become an important factor in international relations with economic strength, which allows it to promote values and standards beyond its borders. At the end of the Cold War, the Union did not consider relations with Russia as a priority of foreign policy 
but as an instrument for stabilizing its external environment and offering a constructive way of solving the post-Soviet space problems.

During the first half of the 1990s under Boris Yeltsin, Russia remained pro-Western oriented, hoping that its contribution to the end of the Cold War would enable it to take its rightful place in the world. ${ }^{5}$ This public attitude was based on the belief that, with the introduction of democracy and a market economy, Russia would soon develop similarly to Western Europe. In order to establish cooperation with new trading partners, Russia embarked on the path of democratization and the establishment of a market economy. However, the reforms were inconsistent and sometimes chaotic, leading to major economic, political, social, and other problems, particularly corruption and crime. The Russians perceived the situation in which Russia found itself in the 1990s as national and personal humiliation. Many attributed their troubles to the Western attempts to impose on Russia a system that did not suit Russian conditions and historical developments. (Hopf, 2006, pp. 662-705).

Despite all the problems, Russia still remained a significant political and economic partner of the European Union. Also, during the 1990s, several important documents were adopted to define and improve mutual relations. The Partnership and Cooperation Agreement signed by the EU and Russia in 1994 had come into force, and it provided the necessary legal framework for the regulation of mutual relations and the preconditions for further development of cooperation between the two parties. ${ }^{6}$ This agreement reflected the EU's efforts to promote reforms in Russia in accordance with the European values in such a manner that the problems that could possibly occur in Russia after the Soviet Union's fall would not "spill" and pose a danger to the Union's security. However, the agreement has had very

\footnotetext{
${ }^{5}$ In the second half of the 1990s, Yeltsin began to pursue a more assertive foreign policy, seeking primarily to respond to accusations that he had sacrificed Russian national interests for the sake of concessions to the West. As part of that, he replaced former Foreign Minister Andrei Kozyrev with Evgeni Primakov, who called for the creation of a multipolar world (Brooks, 2020, p. 5).

${ }^{6}$ The PCA ratification process in the EU was suspended for a time due to Russia's military actions in Chechnya. Notwithstanding Russia's perception that it had every right to wage armed struggle on its territory against the rebels, EU countries unanimously condemned Russia. The ratification process was resumed after Russia, largely under pressure from the Union, found a political solution to the crisis in Chechnya.
} 
limited success in this field. Once this agreement had expired, there were significant differences in the EU's and Russia's views on how the new basic agreement should look and what it should include. The EU was dedicated to a comprehensive and legally binding agreement that would regulate all areas of cooperation, ensure legal harmonization, and provide for the conditionality of cooperation by respecting common European values. Russia claimed that a framework agreement was adequate to regulate mutual relations, which can be complemented by specific technical agreements in other areas of cooperation. ${ }^{7}$

Important foreign policy documents adopted by the two sides in 1999 that defined basic priorities for mutual relations, cooperation, and development prospects were the Common Strategy of the European Union on Russia, and the Medium-Term Strategy for the Development of Relations between Russia and the EU, adopted by Russia. The Common Strategy on Russia was the first EU document of this kind. ${ }^{8}$ This document requests a more effective, operational, and continuous political dialogue that would bring closer the positions of the Union and Russia, and encourage a joint response to security challenges. It points out the importance of preventive diplomacy in conflict prevention and resolution, crisis management, and cooperation within the OSCE and the UN. It advocates stricter control of arms exports, the fight against the proliferation of weapons of mass destruction, and the promotion of nuclear disarmament. The EU also pointed out the need for the implementation of reforms in Russia - "a stable, democratic and prosperous Russia, firmly anchored in a united Europe, is the essence of lasting peace on the continent." (Common strategy of the European Union on Russia, 1999).

Russia responded by formulating an alternative vision of strategic objectives and perspectives for mutual relations. Thus, in 1999, it adopted the Medium-Term Strategy for the Development of Relations between Russia and the EU, which aimed to strengthen Russia's strategic role in international relations and contribute to the creation of a multi-polar world. Russia has expressed interest in the development of the Common Foreign and Security Policy and cooperation with the EU in this area. This was

\footnotetext{
${ }^{7}$ Due to the Ukrainian crisis, the EU also suspended bilateral negotiations with Russia on a new basic agreement.

8 The common strategy introduced by the Amsterdam Treaty in 1997, as the Union's new foreign policy instrument, was supposed to contribute to the greater efficiency of the EU's common foreign and security policy.
} 
supposed to help preserve European security without the isolation of the United States and NATO, but also without their monopoly on the continent. This document highlighted the need for ties between the EU and Russia to result in the emergence of a "pan-European system of collective security" that would enable non-NATO countries to play a greater role. 'Russia, as a world power located on two continents, should have kept the freedom to determine and implement its domestic and foreign policy, its status and advantages of the Euro-Asian country and the largest CIS country, the independence of its position and activities abroad'. ${ }^{\text {' }}$

Although they appear to be similar, significant differences between the EU and Russia's foreign policy strategies and priorities can be identified through careful reading of both documents. As Haukkala notices, the Common Strategy of the European Union emphasizes Europe's values and the need for fundamental reforms in Russia. The Medium-Term Strategy of Russia emphasizes national interests, the sovereignty of the country, and special interests within the CIS (Haukkala, 2010, p. 108). These differences in the concept and understanding of the basic principles, values, and approaches of the EU and Russia are strongly present and often lead to mutual misunderstandings and differences.

The change at the helm of Russia at the turn of 1999 and 2000 made it possible to strengthen its position in international relations. When President Yeltsin appointed Putin as his successor, Russia's domestic and international position was very weak. Although certain freedoms were established, the government was unable to control and effectively manage the territory, and other important international actors did not take into consideration Russia's views and interests (Kanet, 2008/9, p. 5). Putin strengthened federal control and the state apparatus and announced that he would actively work on making Russia an influential state on a global scale again. Over time, Russia became financially independent in relation to the West, due to revenues from energy exports, which were high due to the increase in world prices at that time. Russia achieved a greater degree of political stability, which enabled it to strengthen its impact in the world. (Sleivyte, 2004, p. 60).

\footnotetext{
${ }^{9}$ Russia has special interests, such as relations with the CIS, which the EU should respect, refraining from anything that could be contrary to Russia's interests. Russia's disagreement with, as stated, the EU's efforts to interfere in its sovereign relations through provisions on common values is an important element of the strategy (Стратегия развития отношений Российской Федерации с Европейским Союзомна среднесрочную перспективу (2000-2010 годы), 1999)
} 
Because of the revived growth of the Russian economy and close economic and political linkages of Russia and some EU member states, relations between Moscow and Brussels strengthened in early 2000. Also, Russia turned, above all, to pragmatic cooperation with European countries and institutions, which contributed to the further development of economic and political ties between the Russian Federation and the EU.

With the accession of new candidate countries from Central and Eastern Europe, the border between the EU and Russia was significantly extended, which increased the number of issues on which the two sides needed to cooperate. Russia denied any involvement in the European Neighbourhood Policy, but the two sides established a "strategic partnership". ${ }^{10}$ The EU and Russia's efforts to build a strategic partnership indicated the growing importance of mutual relationships and a shared interest in further developing cooperation. As Ferguson pointed out, the agreement about the strategic partnership was the most ambitious and downright document on the partnership between the EU and Russia. President Putin described it as the "zenith" of Russia's relations with the EU, and at the end of the negotiations on common areas of cooperation, it was presented as a new beginning in the cooperation of those continental neighbours (Ferguson, 2018, p. 293). Russia believed that the basic idea of the strategic partnership between the EU and Russia was a mutual recognition that they considered each other as equal. In addition, it assumed that this comprehensive cooperation would be based on mutual respect and appreciation of the vital interests of the Union, as well as Russia (Jović-Lazić, 2015, pp. 29-40).

\section{DECLINING CONFIDENCE AND EMERGENCE OF DISPUTES IN RELATIONS BETWEEN THE EUROPEAN UNION AND RUSSIA}

In the early 2000s, mutual confidence began to decline despite established cooperation mechanisms and frequent meetings between the EU and

\footnotetext{
${ }^{10}$ At the 2003 EU-RF Summit in St. Petersburg, an agreement was reached on establishing a strategic partnership in four different areas of cooperation of special interest to both sides: foreign and security policy, internal security and justice, economy/energy, education, and culture. Two years later, at the Moscow Summit, the EU and Russia adopted a strategy to operationalize cooperation in four areas defined in the strategic partnership. Specific road maps were agreed upon, setting out the objectives and specific actions necessary to further develop the strategic partnership. In accordance with sanctions imposed on Russia, the EU also suspended the strategic partnership with Russia.
} 
Russia's political leadership. Both sides began to express increasingly different opinions on the subjects under discussion, often demonstrating opposing interests. Moscow tried to build relations with the EU that would allow it to equally engage with Brussels in key political and security decisions when it came to open issues, especially on the European continent. When Russia realized that the EU wanted to build its security and defence structure, which continued to rely primarily on NATO in planning operations and military development, it became openly dissatisfied. Post-cold War Europe was based on Euro-Atlantic structures, and Russia started to demand that its interests should also be taken into account and acknowledged. ${ }^{11}$ That is why it called for a new European security framework, but it was, as Trenin noted, only offered a formal partnership with no special privileges (Trenin, 2017).

Because of this, Russia began to perceive it as a spread of influence of the United States in NATO and the EU's efforts to expand membership and develop cooperation with Eastern Neighbourhood. On the other hand, Forsberg argued that the European security architecture was not imposed on Russia, but was developed by agreements and treaties that this country signed with the EU, the US, and NATO (Forsberg, 2019, pp. 164-167).

Generally speaking, Russia's dissatisfaction with the West started in 1999 with the bombing of the FRY without the approval of the UN Security Council (Trenin, 2006, p. 233). This year was also marked by the accession of Hungary, Poland and the Czech Republic to NATO. It continued with the US decision to withdraw from the ABM Treaty in December 2002, and plans for the deployment of an anti-missile system in Eastern Europe. Most of Russia's resentment came out of NATO's relentless eastward expansion. Also, the political shifts in the post-Soviet states, expressed in 'coloured revolutions' in 2003 in Georgia, 2004 in Ukraine and 2005 in Kyrgyzstan, were seen by Moscow as a product of Western policy aimed at creating pro-Western regimes and reducing Russia's role and influence in this area (Mankoff, 2011). Following the establishment of the European Neighbourhood Policy by Brussels in 2004 and, in particular, the Eastern Partnership in 2009 aimed at developing a partnership with the post-Soviet countries, Russia began to see the EU as a threat to its regional influence and interests. ${ }^{12}$ Russia's concerns

${ }^{11}$ Russia's attitude to the post-Cold War was clearly demonstrated in Vladimir Putin's controversial speech at the Munich Security Conference in February 2007 (Forsberg, 2019, p. 166).

${ }^{12}$ Russia shows a clear interest in the region with which it was once strongly connected. Russia's efforts to maintain and strengthen political, economic, and 
became more serious after the NATO Summit in Bucharest in April 2008, when the US proposed membership action plans for Georgia and Ukraine. Although this was not accepted thanks to France and Germany, which were openly opposed to the proposal, a declaration was adopted at this summit that stated "NATO welcomes Ukraine's and Georgia's Euro-Atlantic aspirations for membership in NATO. We agree today that these countries will become members of NATO." (De Hoop Scheffer, 2008). This confirmed Moscow's fears that NATO might include its 'near abroad' countries in its membership, which are of crucial strategic importance to its national interests. ${ }^{13}$ Just several months after the Bucharest NATO summit, in August 2008, a five-day Russian-Georgian war broke out. The armed conflict and the subsequent recognition of the independence of Abkhazia and South Ossetia by Russia provoked serious tensions in EU-Russia relations (Jović-Lazić, 2008, pp. 30-36). Along with gas disputes between Russia and Ukraine, which directly affected the EU's supply, these events drew attention to the major gaps between the EU and Russia's common neighbourhood priorities and ambitions and their overall mutual relations. In these circumstances, Brussels decided to strengthen its activities in the post-Soviet space by accelerating the process of launching the Eastern Partnership. This is the policy of establishing close, privileged relations with the Eastern neighbours of the EU, which were once part of the Soviet Union. This partnership, which has increased the EU's presence in the post-Soviet space, has further heightened Russia's concerns.

Thus, the Russian Minister of Foreign Affairs, Sergei Lavrov, stated: "We are accused of having spheres of influence. But what is the Eastern Partnership, if not an attempt to extend the EU's sphere of influence?" (Pop, 2008). Medvedev also notified that Russia does not want "the Eastern Partnership to turn into a partnership against Russia" (Amies, 2009). Although not a geopolitical project, this partnership has geopolitical implications. By relying on multilateral agreements and legal agreements aimed at introducing reforms in the region, the Union has clearly underestimated Russia's perception of these initiatives in the post-Soviet

military influence in the post-Soviet states stem from its security, economic, cultural, and identity interests, as well as its aspirations to preserve and strengthen regional and global influence.

${ }^{13}$ By the term 'near abroad' Russia means all the states that emerged on the territory of the former Soviet Union, with the exception of the three Baltic republics. These are Armenia, Georgia, Azerbaijan, Belarus, Moldova, Ukraine, Kazakhstan, Kyrgyzstan, Tajikistan, Turkmenistan, and Uzbekistan. 
region. Especially because Moscow has its own project to promote the Eurasian Economic Union. These two opposing integration projects have collided in Ukraine. Ukraine is a divided country that has tried to find a balance between maintaining stronger relations with the EU and the need to avoid the antagonism of Russia on which it largely depends when it comes to energy supply and trade cooperation. Essentially, Kyiv has long tried to follow a strategy that would allow it to gain the most of its relationships with its major neighbours, the EU, and Russia. However, the clash between different and incompatible EU and Russia integration projects in the common neighbourhood has directly caused the crisis in Ukraine. This country was, as a trading partner, forced to choose between the integration initiatives of the EU and the Russian Federation. ${ }^{14}$ Soon it became apparent that this was an impossible choice for a country in such a specific situation.

Koenig notes that the EU's approach to Ukraine before the crisis was not sufficiently politically thoughtful, but it was too technocratic. Because of that, the decision-makers at the EU level underestimated the geopolitical consequences of the Association Agreement (AA) with Ukraine (Koenig, 2015, p.2). The Ukrainian government's decision to shift its policy course and to give up signing the AA with the Union led to mass anti-government protests on Kyiv's streets. These protests escalated into violence and later led to the overthrow of then-President Viktor Yanukovych, his recall by the parliament, and his leaving the country. The unexpected development of the situation in Ukraine clearly showed that the new government in Kyiv was pro-Western. Russia perceived this as a provocation and potential geopolitical defeat in the largest and most important country within its zone of influence. It became clear that Ukraine's orientation was unacceptable because Russia saw this country as a major buffer state between NATO, the EU, and Russia (Mearsheimer,

${ }^{14}$ Ukraine negotiated with the EU on the Association Agreement and the Comprehensive Free Trade Area from 2007 to 2011. The documents were initialled in 2012, and the EU Foreign Affairs Council soon adopted conclusions confirming that the Union was ready to sign an agreement with Ukraine as soon as it made some progress in fulfilling the conditions set out in the conclusions. Ukraine's efforts to reach an agreement with the EU fuelled tensions in its relations with Russia. Russia warned Ukraine that if it signed agreements with the EU, it would not be able to maintain privileged access to the Customs Union market. At the same time, in exchange for postponing its signing indefinitely, Russia promised Ukraine a reduction in the price of gas by a third and an investment of 15 billion dollars in its government bonds. A combination of threats and economic promises shook the Ukrainian government, which accepted Russia's offer (Haukkala, 2015, pp. 33-34). 
2014). Russia annexed Crimea and fuelled the armed conflicts in eastern Ukraine, which began in April 2014 after pro-Russian separatists seized the local government and security services in various towns in the Donbas. That development of situations turned the so-called EU-Russia strategic partnership into an open confrontation. (Jović-Lazić, Lađevac 2017, pp. 112-141).

In response to the Crimean annexation and Russian support for separatist forces in eastern Ukraine, the EU adopted various restrictive measures against Russia. EU leaders cancelled a meeting with Russian officials scheduled for June 2014, and EU representatives agreed to postpone regular bilateral summits with Russia as part of the suspension of political relations. Negotiations on the bilateral visa agreement as well as on the new basic agreement between the EU and Russia and preparations for the G8 Summit in Sochi were also suspended. Moreover, the EU froze the assets and prohibited certain Russian and Ukrainian officials from entering the territory of the Union. The EU also imposed broad economic sanctions on Russia, to which Russia responded with the so-called counter-sanctions. These sanctions are increasing the problems of mutual cooperation in all areas. Implementing restrictive trade and investment measures have significantly affected economic cooperation and trade policy. The EU was Russia's leading investor until recently and an important source of advanced technological expertise and achievements. At the same time, Russia was a large and dynamic importer of products and facilities of the EU with significant potential for further growth. A large proportion of Russian exports are still going to the Union, as they are primarily related to energy exports, and Russia is an important supplier of EU energy and will become even more dominant.

However, the EU has stressed its readiness to lift sanctions, renew ties and cooperation with the Russian Federation when it begins to make an active and unequivocal contribution in searching for a way to solve the Ukrainian crisis. In 2016, the EU Foreign Affairs Council set out five principles on which future relations with the Russian Federation would be based. The first of these principles explicitly ties the length of EU sanctions to the achievement success in the implementation of the Minsk Agreement about resolving the conflict in eastern Ukraine. ${ }^{15}$

${ }^{15}$ The second principle refers to the strengthening of relations with the EU's Eastern Partners and other neighbouring countries, including the countries of Central Asia. The third principle refers to the reinforcement of resilience when it comes to energy security and hybrid threats. The fourth principle concerns selective cooperation with Russia on issues of EU interest, while the fifth concerns the need to support people-to-people contacts and Russian civil society. (Russell, 2016). 
Despite diplomatic efforts to reduce violence and ensure profound respect for the peace agreement, no permanent peace process has occurred. The two parties continuously accuse each other of breaking the agreement. In addition, the status of separatist areas in eastern Ukraine remains uncertain. Although under certain conditions, the Minsk Agreement provides for their return to Kyiv's control, the leaders of the self-proclaimed republics dismiss it as a possibility. Russia does not want to annex them, but unofficial support continues to make a certain kind of extraterritorial area, which violates the national integrity of Ukraine and prevents any possibility of Kyiv becoming part of European and Euro-Atlantic integration. Such complex circumstances cause the continuation of tension and the so-called smouldering war in eastern Ukraine. (Jović-Lazić, Lađevac 2017, pp. 112-141).

\section{LIMITATIONS AND POSSIBILITIES OF COOPERATION BETWEEN THE EU AND RUSSIA}

There are different explanations for the crisis in current relations between Russia and the EU. Orenstein believes that the problem of the EU$\mathrm{RF}$ relations is based on different visions of Europe, different values, different policies, and economies of the two sides. (Orenstein, 2019, pp. 210). Paul and Larson noticed that Russia, as an increasingly assertive power, wanted to play a more important role in the international order and be seen as an equal partner on the international stage. At the same time, like any other rising powers, Russia signals its demands for status through rhetoric, diplomatic activity, and other measures by which it seeks to show its international intentions (Paul, Larson, Wohlforth, 2014, pp. 3-30). Sakwa stated that Russia was not, as traditionally understood, a rising power and did not seek to question the current world order, but only the position in that order given to it (Sakwa, 2011, p. 199). Thus, Russia is not a revisionist power to break the basis of the international system but, as he also noted, a neo-revisionist power that wants to question the American leadership role in that system (2020, p. 19). For Nuriyev, a deep crisis in the relations between Russia and the West and the imposition of mutual sanctions are part of a geopolitical game, driven by decades of mistrust and competing interests of two sides (Nuriyev, 2018). Trenin pointed out that Russia's refusal to accept a subordinate position in its relations with the EU and the West, in general, was the main reason for their disagreements and misunderstandings (Trenin, 2017). 
Even before the Ukrainian crisis, the mutually acceptable prospects for further development of the strategic partnership between the EU and Russia were not fully agreed upon. It is confirmed by the interrupted and complicated negotiations on a new basic agreement on mutual relations to replace PCA that expired in 2007. Russia has strengthened its economic and political position and does not want to enter into strong legal ties with the EU that would be based on the principles that apply to relations with countries that are in the process of joining the EU. Russia is openly opposed to the EU's normative, value-driven approach, which it sees as an unacceptable attempt to interfere in Russia's internal affairs. Despite the obvious differences in approaches regarding the possible form and content of the new agreement, the general position is that it should be harmonized with the changes that have been made in the meantime to respond more appropriately to the current interests of Russia and the Union. The EU has changed significantly, especially with the accession of new member states. Russia has also undergone significant economic and political reforms with marked ambitions at the international level. The importance and reputation of Russia as an EU partner country implies equal participation by both sides in the process of shaping and defining new relations.

Also, before the suspension of the EU-Russia strategic partnership, its successful implementation was questioned, mainly because both sides had different approaches to resolving open issues. This is the result of the different interests of the EU and Russia, as well as the expectations that both sides have of their mutual relations. It was clear that the implementation of agreed forms of cooperation would be long-term, complex, and asymmetrical and would require not only a political commitment to the development of relations and cooperation but also an even more intensive concrete commitment on both sides. This is particularly evident when it comes to energy, where there are mutual interests for interdependencebased cooperation, but also the general failure of a multi-year dialogue and negotiation. It is a consequence of the profound differences in Russia's and the Union's energy policies, which look differently at issues relating to sustainability, development, distribution, transport, and energy usage. The EU policy, which seeks to increase its resilience in the event of energy supply disruptions, aims to liberalize the energy market. It is contrary to Russia's interests, which expect the EU to provide more opportunities for its companies to invest in Europe's oil and gas distribution networks. However, despite the ongoing crisis in mutual relations, Russia is expected to remain a key supplier of energy to the EU and become even more dominant in the future. (Jović Lazić, Nikolić, 2013, pp. 64-82). 
Relations with the EU are what Russia sees as an opportunity to create a new European security architecture. Moscow believes that Russia, as well as the EU, should play a more significant role in this area than before. In practice, the EU countries do not separate the issue of general European security from NATO, which Russia considers contrary to its interests. In that context, Russia wants to determine the position of an independent centre of influence, emphasizing the importance of respecting the specifics of its historical path. Russia is also particularly interested in being seen as an equal and legitimate power in international relations and to preserve its influence in the countries of its 'near abroad'. This is the main reason why it strongly opposes the EU's aims of supporting economic integration and close political cooperation with its Eastern neighbours and has its own 'near abroad' strategy and policy. Strategically speaking, Russia has always shown a tendency to surround itself with 'buffer zones' in order to protect itself from invasions and external instabilities. In this context, the interest of Russia in the neighbourhood is a consequence of concern for national security or concerns that by jeopardizing its influence in the 'near abroad' countries, a kind of barrier between Russia and possible enemies would be endangered. As Ademmer, Delcourc, and Wolczukd point out, Moscow sees them as its sphere of influence and also the last barrier to limit the spread of pro-Western ideas to Russia itself (Ademmer, Delcourc, Wolczukd, 2016, p. 2).

Thus, irrespective of the EU's motives, it has become apparent that the Eastern Partnership's strategic ramifications should be also taken into account. Russia sees this as a kind of strategic weapon in which the EU finds a comparative geopolitical edge in its neighbourhood. Assuming that the Eastern Partnership is designed to bind the eastern neighbours to the EU, keep Russia out of the region, and put the issue of their eventual EU membership off the agenda, Jarabik concludes that these goals have been achieved to a very limited extent and that the region has become neither more stable nor more secure (Jarabik, 2019). On the other hand, Cornell emphasizes that these conflicts are, above all, the result of Russia's aspirations to preserve a key influence in the region. Therefore, he raises the question of how the EU did not anticipate Russia's ability to use military force to prevent Ukraine from coming closer to it. Although he does not blame the EU for growing insecurity in the neighbourhood, he points out that it is unclear how European leaders did not understand the political and ideological consequences of the Eastern Partnership that they were gradually building (Cornell, 2014, pp. 180-181). 
While Moscow's attitudes and strategies towards the post-Soviet countries are well known, the Ukrainian crisis demonstrated Russia's readiness to use force to counter the EU strategy in the region of its specific interest. Due to its position in the Ukrainian crisis and the annexation of Crimea, the EU has accused Russia of violating international law provisions and imposed sanctions on it. The EU has also criticized Russia for using different tactics to control these countries' domestic and foreign affairs and impacting the right of those countries to pursue an independent foreign policy. However, it is obvious that both sides want to establish dominant influence over the common neighbourhood. It has led the region to become a kind of a testing ground for EU-Russia rivalry, their conflicting initiatives, and visions.

Despite the EU's weak commitment to the Eastern Partnership, European officials often point out that it cannot simply ignore the desires of these countries for Europeanisation, democratization, and modernization, and that turning back on such demands would mean abandoning engagement with the core European norms and values. According to this attitude, the EU is mainly interested in the fact that Russia should do its utmost to ensure that the Minsk Peace Agreement is implemented. It is not a straightforward matter, considering that there is a dispute between Moscow and Kyiv as to the next step that should be taken to ensure the implementation of this agreement.

The EU continues to extend its sanctions against Russia, even though they have not been effective. Although sanctions have badly harmed the Russian economy, Russia will keep a significant role in shaping the architecture of the post-Soviet region. Sanctions are simply a response to recent events in Ukraine, but they are not a means of achieving the EU's politically realistic strategic objectives in this country. Due to their geopolitical vulnerability, regardless of whether they are members of the Eastern Partnership and the Eurasian Economic Union, countries of common EU-Russia neighbourhoods are exposed to a kind of 'crossfire of sanctions.' The EU and Russia have a responsibility to help these countries develop successfully, without endangering their sovereignty. Despite all disagreements and differences, this is in the interests of both sides as well as the overall improvement of EU-Russia relations. Also, an effective resolution of key current and future open international issues cannot be achieved without active engagement and cooperation between the EU and Russia. The international arena offers numerous examples of where the EU and Russia have common interests and can thus cooperate (fighting against 
terrorism, preserving the Iranian nuclear agreement, resolving the crisis in North Korea, ending the war in Syria, commitment to the Paris Agreement on climate change, etc.). Selective participation and collaboration in this type of global problems are both necessary and likely. That is the key explanation of why attempting to isolate Russia is a mistake, irrespective of whether its position is getting stronger or weaker.

\section{CONCLUDING REMARKS}

Despite the long-term dialogue, a well-developed communication system at many levels, and accumulated legal bases, the overall scope of the EU-Russia cooperation has always lagged behind political commitments and real possibilities. It is partly because Russia's relations with the EU, and with the West in general, did not contribute to its desired inclusion in the new international order which appeared after the end of the Cold War, or to the creation of a new European security structure independent of NATO. However, in the 1990s, Russia was too weak to move things in its interests and was prepared to develop pragmatic cooperation with the EU. The EU hoped that cooperation with Russia would deepen its democratic reforms and ensure acceptance of Western values. On the contrary, the EU's normative approach has caused a lot of political misunderstanding between the Union and Russia. Russia does not accept the EU's efforts to use norms, values, and achievements as the main criterion and foreign policy instrument that should ensure stability, security, and development on the European continent. When strengthened, a strong commitment to multipolarity becomes a fundamental principle of Russia's foreign and security policy. Russia has begun to openly oppose the values, principles, and policies of the EU, insisting on its right to protect its sovereign democracy and its interests in the post-Soviet region.

The competing interests of the EU and the Russian Federation are clearly expressed in their strategies towards the countries situated between them geographically. However, the Russian-Georgian armed conflict in 2008 that was followed by Russia's recognition of the independence of Abkhazia and South Ossetia, pointed out the need for careful monitoring of the bilateral relations between the EU and Russia and their policies towards a common neighbourhood. The Ukraine crisis showed that the rivalry and opposing interests of Russia and the EU in the common neighbourhood were very strong. The future of EU-Russia relations will depend on the outcome of the 
implementation of the Minsk Peace Agreement and the further development of the situation in Ukraine.

Although the possibility of restoring mutual trust is a very complex issue, it is necessary to maintain the channels of communication open in an effort to find a way to exchange information between the EU and Russia. The current situation has not only affected the interests of the EU and Russia but also have far-reaching negative consequences for international economic and political relations as a whole. The European Union and Russia have a significant role to play in preserving European security and stability, which is the main reason why they should reconsider their current mutual relations, approaches, measures, and expectations. That is the main reason why cooperation is expected to continue, regardless of difficulties, concerns, and instability.

\section{REFERENCES}

Ademmer, E \& Delcourc, L \& Wolczukd, K. (2016). Beyond geopolitics: exploring the impact of the EU and Russia in the 'contested neighborhood', Eurasian Geography and Economics, Vol. 57, No. 1, p. 2.

Adomeit, H. (1979). The Soviet Union and the Western Europe: Perceptions. Policies, Problems, Centre for International Relations, Ontario, p. 20.

Amies, N. (2009). EU-Russia summit reveals differences rather than agreement. Deutsche Welle, retrieved from https://www.dw.com/ en/ eu-russia-summit-reveals-differences-rather-than-agreement/a4271011. Accessed 27 July 2020.

Brooks, S. (2020). The Rise of Putin's Russia and the post-Soviet Conflicts. Post-Soviet Conflicts: The Thirty Years' Crisis, Lasha Tchantouridzé, Stefan Brooks, Ali Askerov (eds.), London, p. 5.

Checkel, J. (1993). Ideas, Institutions, and the Gorbachev Foreign Policy Revolution. World Politics, Vol. 45, Issue 02, p. 297.

Cornell, S. (2014). The European Union: Eastern Partnership vs. Eurasian Union, in: S, Frederick S, Cornell (Eds.), Putin's Grand Strategy: The Eurasian Union and Its Discontents, pp. 180-181.

De Hoop Scheffer, J. (2008). Press conference by NATO Secretary General Jaap de Hoop Scheffer, retrieved from https:/ / www.nato.int/cps/en/ natohq/opinions_7619.htm?selectedLocale=en. Accessed 27 June 2020.

Ferguson, I. (2018). Between New Spheres of Influence: Ukraine's Geopolitical Misfortune. Geopolitics, 23:2, p. 293. 
Forsberg, T. (2019). Russia and the European security order revisited: from the congress of Vienna to the post-cold war. European Politics and Society, 20:2, pp. 164-167.

Haukkala, H. (2010). The EU-Russia Strategic Partnership: The Limits of PostSovereignty in International Relations, Routledge, p. 108.

Haukkala, H. (2015). From Cooperative to Contested Europe? the Conflict in Ukraine as a Culmination of a Long-term Crisis in EU-Russia relations, Journal of Contemporary European Studies, Vol. 23, No. 1, pp. 25-34.

Hopf, T. (2006). Moscow's foreign policy, 1945-2000: Identities, institutions and interests, in: R, Suny (Ed.), The Cambridge History of Russia. Cambridge University Press, pp. 662-705.

Jarabik, B. (2019). Analysis, Eastern Partnership at 10. Rhetoric, resources and Russia. New Eastern Europe, Issue 3-4, retrieved from https://neweasterneurope.eu/2019/05/02/eastern-partnership-at-10rhetoric-resources-and-russia/. Accessed 17 June 2020.

Jović Lazić, A \& Nikolić, M. (2013). The Importance of Energy Security in the Relations of the European Union and Russia, in: Antevski M. \& Vesić D. (Eds.), Energy security of Europe: The Position of Serbia, IIPE, pp. 64-82.

Jović-Lazić, A. \& Lađevac I. (2017). Ukrainian Crisis as a Security Challenge of the Contemporary World, in: Đorđević, B \& Tsukimura, T. \& Lađevac I. (Eds.), Social and economic problems and challenges in the Contemporary World, Global Resource Management: Doshisha University, Japan, IIPE, Belgrade, pp. 112-141.

Jović-Lazić, A. (2015). Odnosi između Evropske unije i Ruske Federacije: kraj XX $i$ početak XXI veka. [Relations between the European Union and the Russian Federation: the end of the XX and the beginning of the XXI century], IMPP, Beograd, pp. 29-40.

Jović-Lazić, A. Sukob u Gruziji i Evropska unija, [Conflict in Georgia and the European Union], Medunarodna politika, Vol. LIX, br. 1130, pp. 30-36.

Kanet, R. (2009). Russia and the European Union: The U.S. Impact on the Relationship, Jean Monnet/Robert Schuman Paper Series, Vol. IX, No. 2, p. 5.

Koenig, N. (2015). The External Challenges of the EU: What Strategies? Discussion of European Steering Committee, Synthesis, Jacques Delors Institut, Berlin, p. 2.

Mankoff, J. (2011). Russian Foreign Policy: The Return of Great Power Politics. Lanham.

Mearsheimer, J. (2014). Why the Ukraine Crisis Is the West's Fault: The Liberal Delusions That Provoked Putin. Foreign Affairs, Vol. 93, No. 5, 
pp. 77-89, retrieved from https://www.foreignaffairs.com/articles/ russia-fsu/2014-08-18/why-ukraine-crisis-west-s-fault. Accessed 18 January 2021.

Nuriyev, E. (2018). Endless Endgame: Whither Russia-West Confrontation?. Russia in Global Affairs, retrieved from https://eng.globalaffairs.ru/ articles/endless-endgame-whither-russia-west-confrontation/. Accessed 28 June 2020.

Orenstein, M. (2019). The Lands in Between: Russia vs. the West and the New Politics of Hybrid War. Oxford University Press.

Paul, D. \& Larson, W \&, Wohlforth, W. (2014). Status and World Order, in: Paul, D. \& Larson, W \&, Wohlforth, W. (Eds.). Status in World Politics, Cambridge University Press, pp. 3-30.

Pop, Valentina. (2009). "EU expanding its 'sphere of influence,' Russia says", EU Observer, retrieved from https://euobserver.com/foreign/27827. Accessed 27 August 2020.

Russell, M. (2016). The EU's Russia policy: five guiding principles, retrieved from https:// www.europarl.europa.eu/RegData/etudes/BRIE/2016/ 589857/EPRS_BRI(2016)589857_EN. Pdf. Accessed 27 July 2020.

Sakwa, R. (2020). Greater Russia: Is Moscow out to subvert the West?. International Politics. https://doi.org/10.1057/s41311-020-00258-0, p. 19.

Sakwa, Richard, (2011). Russia and Europe: Whose Society?. Journal of European Integration, 33:2, p. 199.

Sleivyte, J. (2004). Putin's Regime and Consolidation of the State. Baltic Defence Review, No 12, Tartu, p. 60.

Trenin, D. (2017). Russia's evolving grand Eurasia strategy: Will it work?. Carnegie Moscow Center, retrieved from http:// carnegie.ru/2017/07/ 20/russia-s-evolving-grand-eurasia-strategy-will-it-work-pub-71588. Accessed 28 July 2020.

Webber, M. (2000). Russia E Europe: Conflict or Cooperation?. Palgrave Macmillan, New York, p. 66.

Trofimenko, H. (1991). Soviet policy vis-a-vis Europe: a Soviet view, in: Jyrki Iivonen (ed.), The changing Soviet Union in the new Europe, Aldershot, 1991, pp. 3-27.

Тренин, Д. (2006). Политические отношения России с США и Евросоюзом: союзники, партнеры, соперники. Интеграция и идентичность: Россия как “новый Запад”, Москва, с. 233. 